\title{
Onshore wind energy use in spatial planning-a proposal for resolving conflicts with a dynamic safety distance approach
}

\author{
Georg Felber and Gernot Stoeglehner
}

\begin{abstract}
The political agenda on wind power usage intends its further expansion in a large scale. As most energy sources, wind power can have negative impacts on humans and environment; this expansion can be accompanied by land use conflicts with land uses sensitive to disturbance. During operation, disturbances from noise, shadow, or ice throw can occur. Due to the dimensions of modern wind power systems, wind power farming can pose a threat to birds and bats (collision and avoidance) and may also lead to a change of landscape sceneries, which can cause conflicts with residents, nature conservation, or tourism interests. Therefore, the control of wind power expansions by spatial planning plays a key role for the mitigation of negative impacts as well as for its public acceptance. Spatial planning offers instruments to resolve potential conflicts with affected stakeholders. On a regional level, the determination of priority and exclusion areas for the use of wind power based on functional criteria represents the most essential planning measure.

For the protection of affected residents and nearby housing areas, safety distance regulations are normally applied. Since most distance regulations are defined as fixed distance values, the question arises: if a static approach sufficiently considers the technical state and the further development of wind power systems with increasing plant heights as well as cumulating effects of large wind farms, i.e. cumulated noise effects that rise with the number of spin wheels. To take these factors better into account, the determination of safety distance could be dynamically bound to power plant height and wind farm size. This article introduces a dynamic approach for dimensioning safety distances, which consists of a formula to calculate distances in relation to the height of the wind power plants and the number of spin wheels. The formula takes shading, noise, and icefall into account. It is relevant for wind farm planning, as it does not only allow for determining distances from sensible land uses to wind power plants, but also allows for assessing variants of wind farms in terms of height and number of the spin wheels in a given area.
\end{abstract}

Keywords: Wind power development; Environmental effects; Spatial planning; Safety distances; Impact mitigation

\section{Background}

European Union energy and climate protection policies aim at the reduction of greenhouse gas emissions of $20 \%$ until 2020 [1] and $80 \%-95 \%$ until 2050 [2]. This is only possible by combining energy efficiency with the extensive use of renewable energy sources. Wind energy plays an important role in strategy building for sustainable energy supplies both on-shore and off-shore. For instance,

\footnotetext{
* Correspondence: gernot.stoeglehner@boku.ac.at

Institute of Spatial Planning and Rural Development, Department of Spatial, Landscape and Infrastructure Sciences, University of Natural Resources and Life Sciences Vienna, Peter-Jordan-Straße 82, 1190, Vienna, Austria
}

in Germany, renewable energy policies determined the realization of $45.750 \mathrm{MW}$ until 2020 [3]. In 2013, a total wind power capacity of $34.179 \mathrm{MW}$ was installed (47.4 TWh), which covered $8 \%$ of the German gross electricity consumption [4]. In Austria, the Renewable energy law targets a wind power capacity of $3.000 \mathrm{MW}$ until 2020 [5], whereas in 2013, wind power plants with a total capacity of $1.684 \mathrm{MW}$ were installed [6], covering $5.2 \%$ of Austria's gross electricity consumption from 2012 [7].

On the one hand, wind energy is favorable because of the energy efficiency of the technology. It only takes up to 18 months to fully regenerate the energy demand to 
produce and install a wind power plant [8]. Therefore, wind energy has a relatively low ecological footprint compared to other means of electricity generation and is extensively available without being in conflict with other land uses like food production [9]. On the other hand, wind energy has relatively little on-site environmental effects compared to other means of electricity generation.

Problems arise from noise emissions, shading, ice falling, killing, or displacement of certain sensitive bird and bat species and, finally, change of landscape sceneries. These effects grow largely with the size of the wind turbines, which are up to $200 \mathrm{~m}$ at the moment, and may lead to resistance against wind power usage in local populations, nature protection, and tourism $[10,11]$. Especially, the negative impact on housing areas by noise and shading emissions as well as the landscape transformation related to the wind power expansion play a key role for the sustainable wind power usage.

Therefore, spatial and environmental planning regulations are needed to control the spatial distribution, size, and amount of wind power plants. In general, the siting and permissibility of wind power plants can be directed by local and regional planning measures. At a regional level, areas can either be determined for a priority wind energy usage or exclude its usage, based on certain eligibility criteria in the form of predefined planning guidelines. Furthermore, specific, legally binding preconditions for devoting corresponding areas in the municipal land use plan can be postulated for the planning process at a local level. This article analyzes the spatial planning regulations for on-shore wind power plants in Austria compared to Germany and shows how environmental problems concerning wind power usage are tackled with appropriate planning measures. Based on this analysis, shortcomings of the existing regulations are identified and a new approach for defining safety distances between wind power plants and subjects of protection is introduced. Finally, some conclusions are drawn.

\section{Mitigating environmental effects of wind energy with spatial planning measures}

While side effects of the wind power usage as interference of bird and bat species or the change of landscape sceneries cause primarily nature protection-related impacts, effects such as noise and shading emissions have negative impacts on affected housing areas and in further consequence on the quality of living for local residents.

Currently used wind power plants can emit sound power levels of up to $107 \mathrm{~dB}$ at full operation [12,13], which is comparable with the loudness of a chainsaw [14]. Moreover, an increasing number of wind power turbines, respectively sound sources, may lead to a cumulative sound power level and ultimately to a higher noise emission depending on size and layout of a wind farm $[15,16]$.
The impact of moved shading caused by the rotor turning can significantly affect emission targets located around a wind power plant in a distance of up to $750 \mathrm{~m}$, based on studies on a $140-\mathrm{m}$ wind power plant. Due to the size of modern wind power plants with heights up to $200 \mathrm{~m}$, the impact range is likely higher $[17,18]$.

In order to mitigate these impacts, on a regional level, priority zones can be determined based on certain admission requirements. Commonly, the assessment is made by evaluating wind power-related impacts on fields like spatial planning, landscape scenery, nature conservation, and, in some cases, tourism. Depending on the existing spatial resistance, areas are eligible or ineligible for wind power usage. On a regional and local scale, certain criteria can be determined for the zoning of wind power areas, which are specified in the course of the spatial planning process. In particular, the compliance of minimum distances between wind power plants and housing areas plays a key role for the legal admissibility, since certain limit values for noise and shading have to be complied.

In addition, public participation in wind power projects can also play an important role in the planning process of wind farms and in further consequence in improving the acceptability of wind power projects [19].

\section{Analysis of spatial planning regulations}

In recent years in Austria, the expansion of wind power increased heavily and thereby in several Austrian provinces, regulation instruments were implemented. In Burgenland, a regulation program was already introduced in 2002. Starting from 2010 in Upper Austria, Carinthia Styria, and, finally, in Lower Austria, further regulatory instruments were implemented, which arrange the wind power expansion based on certain criteria. The comparison of the wind power regulations showed that for determining exclusion areas, the issues of spatial planning, landscape scenery, and nature conservation were taken into account. Concerning nature protection, all regulatory frameworks exclude protected areas from wind farm developments. Some remaining issues outside of protected areas, e.g. the protection of bird migration routes, were dealt with in baseline studies for the specific regulations. Methodological differences could be detected when the issues spatial planning and landscape scenery were addressed.

With regard to the assessment of the impact on landscape sceneries, the Carinthian regulation determined quantitative visibility criteria for the admissibility of wind farms. Based on visibility limits of potential wind farming areas from surrounding housing areas, the admissibility for the construction of wind farms had been determined, where admission requirements become more restrictive with increasing hub height of the wind power plant [20]. 
The criteria were derived based on a GIS analysis covering the whole territory of the province.

In spatial planning, the determination of minimum distances between wind turbines and residential areas in order to mitigate noise and shading effects showed a large bandwidth within the existing regulations. While in Carinthia this distance was defined with 1,500 m, Lower Austria set with $1,200 \mathrm{~m}$, Burgenland and Styria with $1,000 \mathrm{~m}$, and Upper Austria with $800 \mathrm{~m}$ as a minimum spacing value.

In Germany, the increase of wind power expansion already started in 1997, when wind power projects were legally fixed as privileged construction ventures [21]. Basically, the regulation of wind power siting is similar to the Austrian planning situation, although the planning standards in the individual provinces are more consistent. On the regional level, priority or exclusion zones for wind power plants are determined and made legally binding in the respective regional planning instruments (regional plans). By means of wind power decrees in recent years, further planning guidelines with detailed information on planning and legal requirements for wind power projects were elaborated.

On a local level, municipalities can also define areas for wind farms in the communal zoning plan. Local authorities can locate priority areas and may exclude remaining areas for wind power usage at the same time. But they are encouraged to develop a planning concept for the whole municipal territory so that the decision for or against wind power areas can be justified. But since wind power projects represent privileged projects by law, it is not possible for municipalities to entirely exclude wind power usage on their territory, if the legal requirements for usage are met, unless other substantial public concerns justify an exclusion [22-24].

Regarding the spatial planning regulations for safety distances between wind power plants and housing areas in the German provinces, the range covers distances between $500 \mathrm{~m}$ (e.g. Hamburg) and 1,000 m (e.g. Mecklenburg). In particular cases, the distance is calculated from the tenfold total height of a wind power plant, which means values up to $2,000 \mathrm{~m}$ (e.g. Saxony-Anhalt) [25] (Table 1).

As conflicts with nature protection and landscape scenery have to be subject to case-by-case examination, the further article is focussed on safety distance approaches, addressing shading and noise protection.

\section{Discussion of safety distance approaches}

These safety distances have the purpose to protect local residents from impairment through noise and shading effects. Impacts from ice falling will be excluded from further discussion, since the impact range of slung ice pieces can be estimated by the 1.5-fold length of the tower height plus rotor diameter, and, therefore, is in any case smaller than the distances for noise protection or shading [26,27]. According to that, the ice falling range for the biggest wind power plants with a height of $200 \mathrm{~m}$ is limited with $400 \mathrm{~m}$. In the existing planning regulations, the distance values were largely set as static values. Furthermore, the question arises if such static distance approaches can meet technical developments and if they are capable to take the technical progression of modern, large-scaled wind power plants into account.

Regarding the noise emissions from wind turbines, it is considered realistic to estimate a maximum sound power level of $110 \mathrm{~dB}$ (summed sound power level of several wind turbines) in order to determine adequate safety distances. It was assumed that noise emissions of newer wind power systems will not change significantly anymore [28]. Currently used wind power plants such as the Enercon E-101 (3 MW) or the Vestas V112 (3 MW) produce maximum sound power levels up to $107 \mathrm{~dB}$ in full operation $[12,13]$. In this context, the number of wind turbines, respectively sound sources, affect the sound pressure intensity. Several sound sources must be considered additive, since these can sum up and amplify, so that higher safety distances could be necessary, dependent on the respective noise emission limit of the affected housing area with a bottom line of $35 \mathrm{~dB}[15,16]$. The noise values of the different power plant configurations in Table 2 were calculation results of a noise prediction algorithm, an alternative procedure for the DIN ISO 9613 (ISO standard for noise emission prognosis), which is recommended by the German 'Länderausschuss für Immissionsschutz' (Federal Committee for Air Pollution Control) for wind power plant approvals. The uncertainty of the prognosis was taken into account by adding a 'safety charge' of $2.5 \mathrm{~dB}$ [29]. The stated noise limit of $40 \mathrm{~dB}$ within Table 2 corresponds roughly to the background noise in a library [30].

For assessing shading emissions, generally shading periods of a maximum of $30 \mathrm{~h}$ per year and a maximum of 30 min per day are regarded as not significantly irritating $[17,26,31]$. Figure 1 shows the shading progression of a wind power plant with a total height of $140 \mathrm{~m}$ with a maximum shading range in eastern and western direction on a plain area. It can be seen that at a minimum distance of $750 \mathrm{~m}$ from the affected emission target wind power plants can be considered as not significantly irritating. Higher power plants with total heights up to $200 \mathrm{~m}$ require increased safety distances [17] (see Figure 1).

According to the outlined statements, the intensity of noise and shading emissions of a wind power plant is dependent from the variable parameters, number of wind turbines, type (respectively loudness), and height, which steadily change in view of the continuous progression of the wind power technology. Since 1990, the size of wind 
Table 1 Overview of Austrian and German regulation instruments for wind power development and the corresponding minimum safety distances to housing areas

\begin{tabular}{|c|c|c|}
\hline Province & Regulation instrument & $\begin{array}{l}\text { Minimum safety distances to } \\
\text { housing areas }\end{array}$ \\
\hline Burgenland (Austria) & $\begin{array}{l}\text { Regional planning framework concept for wind energy } \\
\text { (2010) }\end{array}$ & $1,000 \mathrm{~m}$ \\
\hline Carinthia (Austria) & Directive on wind energy allowance zones (2012) & $1,500 \mathrm{~m}$ \\
\hline Lower Austria (Austria) & $\begin{array}{l}\text { Sectoral spatial planning program on wind energy use } \\
\text { (2014) }\end{array}$ & $1,200 \mathrm{~m} ; 2,000 \mathrm{~m}$ \\
\hline Upper Austria (Austria) & $\begin{array}{l}\text { Wind master plan Upper Austria (2012), Upper Austrian } \\
\text { law on electricity economy and organization }\end{array}$ & $800 \mathrm{~m}$ \\
\hline Styria (Austria) & $\begin{array}{l}\text { Sectoral spatial planning program on wind energy use } \\
\text { (2013) }\end{array}$ & $1,000 \mathrm{~m}$ \\
\hline Baden-Württemberg (Germany) & Decree on wind energy Baden-Württemberg (2012) & - \\
\hline Bayern & $\begin{array}{l}\text { Guidance on planning and approval of wind power } \\
\text { plants (2011) }\end{array}$ & $800 \mathrm{~m}$ \\
\hline Brandenburg/Berlin (Germany) & $\begin{array}{l}\text { Guidance for regional planning associations on the } \\
\text { zoning of wind energy suitability zones (2009) }\end{array}$ & $1,000 \mathrm{~m}$ \\
\hline Hamburg (Germany) & Exclusion zones for wind energy in Hamburg (2010) & $500 \mathrm{~m}$ \\
\hline Hessen (Germany) & $\begin{array}{l}\text { Recommendations about distances between spatially } \\
\text { relevant wind energy plants and areas and facilities } \\
\text { worthy of protection (2010) }\end{array}$ & 1,000 m; case-by-case examination \\
\hline Mecklenburg-Vorpommern (Germany) & $\begin{array}{l}\text { Directive on realignment, modification, or amendment } \\
\text { of regional plans in Mecklenburg-Vorpommern (2012) }\end{array}$ & $1,000 \mathrm{~m}$ \\
\hline Niedersachen (Germany) & $\begin{array}{l}\text { Recommendations about the determination of priority } \\
\text { and suitability zones for wind energy use (2004) }\end{array}$ & $1,000 \mathrm{~m}$ \\
\hline Nordrhein Westfalen (Germany) & $\begin{array}{l}\text { Decree about planning and approval of wind energy } \\
\text { plants and advice for objectives and implementation } \\
(2011)\end{array}$ & $\begin{array}{l}\text { case-by-case examination; calculation } \\
\text { according to TA Lärm (technical } \\
\text { standard for noise assessment) }\end{array}$ \\
\hline Rheinland-Pfalz (Germany) & $\begin{array}{l}\text { Advice for the assessment of admissibility of wind } \\
\text { power plants (2006) }\end{array}$ & $1,000 \mathrm{~m}$ \\
\hline Saarland (Germany) & Guidance for wind energy use in Saarland (2012) & $\begin{array}{l}\text { case-by-case examination, } \\
\text { depending on type of plant }\end{array}$ \\
\hline Sachsen (Germany) & $\begin{array}{l}\text { Separate approaches by the regional planning } \\
\text { associations }\end{array}$ & $750-1,000 \mathrm{~m}$ \\
\hline Sachsen-Anhalt (Germany) & $\begin{array}{l}\text { Separate approaches by the regional planning } \\
\text { associations }\end{array}$ & $\begin{array}{l}1,000 \mathrm{~m} \text {; size of WPP >100 m: } 10 \times \text { of } \\
\text { the total height }\end{array}$ \\
\hline Schleswig-Holstein (Germany) & $\begin{array}{l}\text { Guiding principles about the planning and } \\
\text { implementation of the impact regulation under nature } \\
\text { protection law concerning wind power plants (2012) }\end{array}$ & $800 \mathrm{~m}$ \\
\hline Thüringen (Germany) & $\begin{array}{l}\text { Recommendations for the amendment of regional } \\
\text { plans concerning priority areas for wind energy, which } \\
\text { function as suitability zones (2005) }\end{array}$ & $\begin{array}{l}\text { case-by-case examination; appraisal } \\
\text { zone of } 1,000 \mathrm{~m}\end{array}$ \\
\hline
\end{tabular}

Table 2 Minimum distances to comply to the noise emission limit of $\mathbf{4 0}$ and $\mathbf{3 5} \mathrm{dB}$ for housing areas [16]

\begin{tabular}{llllll}
\hline Configuration & \multicolumn{2}{l}{ Silent operating: $\mathbf{1 0 4 . 5 ~ d B}$} & & \multicolumn{2}{l}{ Normal operating: $\mathbf{1 0 7 . 5} \mathbf{d B}$} \\
\cline { 2 - 3 } \cline { 5 - 6 } & Noise limit: $\mathbf{4 0 ~ d B}$ & Noise limit: $\mathbf{3 5 ~ d B}$ & & Noise limit: $\mathbf{4 0 ~ d B}$ & Noise limit: $\mathbf{3 5 ~ d B}$ \\
\hline Single spin wheel & $520 \mathrm{~m}$ & $770 \mathrm{~m}$ & $660 \mathrm{~m}$ & $980 \mathrm{~m}$ \\
Five spin wheels in a field & $780 \mathrm{~m}$ & $1,200 \mathrm{~m}$ & $1,000 \mathrm{~m}$ & $1,490 \mathrm{~m}$ \\
Seven spin wheels in a line & $880 \mathrm{~m}$ & $1,370 \mathrm{~m}$ & $1,160 \mathrm{~m}$ & $1,700 \mathrm{~m}$ \\
Twenty-one spin wheels in a field & $1,040 \mathrm{~m}$ & $1,600 \mathrm{~m}$ & $1,375 \mathrm{~m}$ & $2,060 \mathrm{~m}$ \\
\hline
\end{tabular}




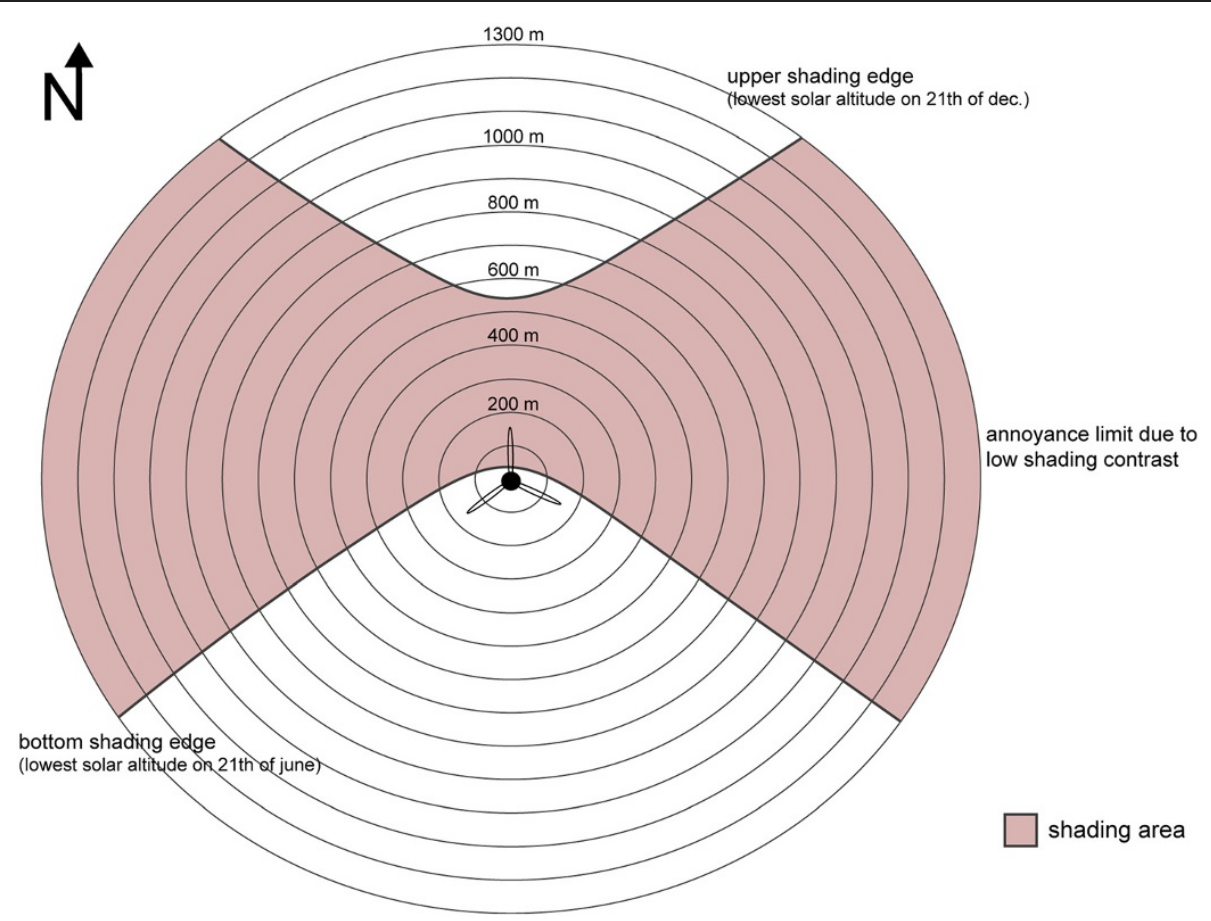

Figure 1 Potential shading area of a 140-m wind power plant (north-oriented) [after 26].

power plants more than tripled with the jump up to total heights of $200 \mathrm{~m}$ in 2008 [28]. For the further development of low-wind sites, even higher towers should be installed to benefit from constant wind conditions in these heights. The development of hub heights is estimated at $150 \mathrm{~m}$ by 2033, with rotor diameters of $140 \mathrm{~m}$ [32].

\section{A new approach for dynamic safety distances}

In order to take better account of these variable parameters, safety distances should be bound dynamically to a particular height of a wind power plant, the size, and the number of wind turbines of a wind farm. One approach would be to determine the required safety distances by taking the size of a priority area for wind power usage and, therefore, the feasible number of wind power plants, the affected housing area with its respective noise limit, and the power class of the wind turbine as well as the operating mode (e.g. silent operation during night) into account [16].

This approach could be evolved by calculating safety distances on the basis of a formula involving the possible number of power plants (and as a consequence, the accumulated noise level of several sources) and the total power plant height. By including these parameters, it would be possible to determine the safety distance dynamically:
Taking the fivefold rotor blade tip height into account should estimate the safety distances to mitigate disturbances by shading emissions more precisely and caserelated. With the multiplication of this parameter by the factor $(1+(0.05 \times$ number of power plants $))$, it is possible to approximate the accumulated sound level of multiple wind turbines and to adjust the safety distance accordingly. Thus, an increasing number of wind turbines would also increase the distance value, especially of tall power plant types, which could take up a 'high' value compared to static safety distance values in existing planning regulations (see Figure 2). As a consequence, the dominance of large wind farms and the cumulative effects of a high number of wind power plants as well as the further technical development of wind power systems with increasing dimension might be better taken into account.

The presented formula was derived iteratively to meet emission patterns of wind power plants according to the results of the above described wind power plant approval assessments (Table 2). Once the general structure of formula was found, a calibration was exercised to see how accurate the formula can take emission patterns in relation to height and number of power plants into account. In this iterative process, we calibrated the formula to the factor ' 0.05 ' in the part of the equation ' $(1+(0.05 \times$ 


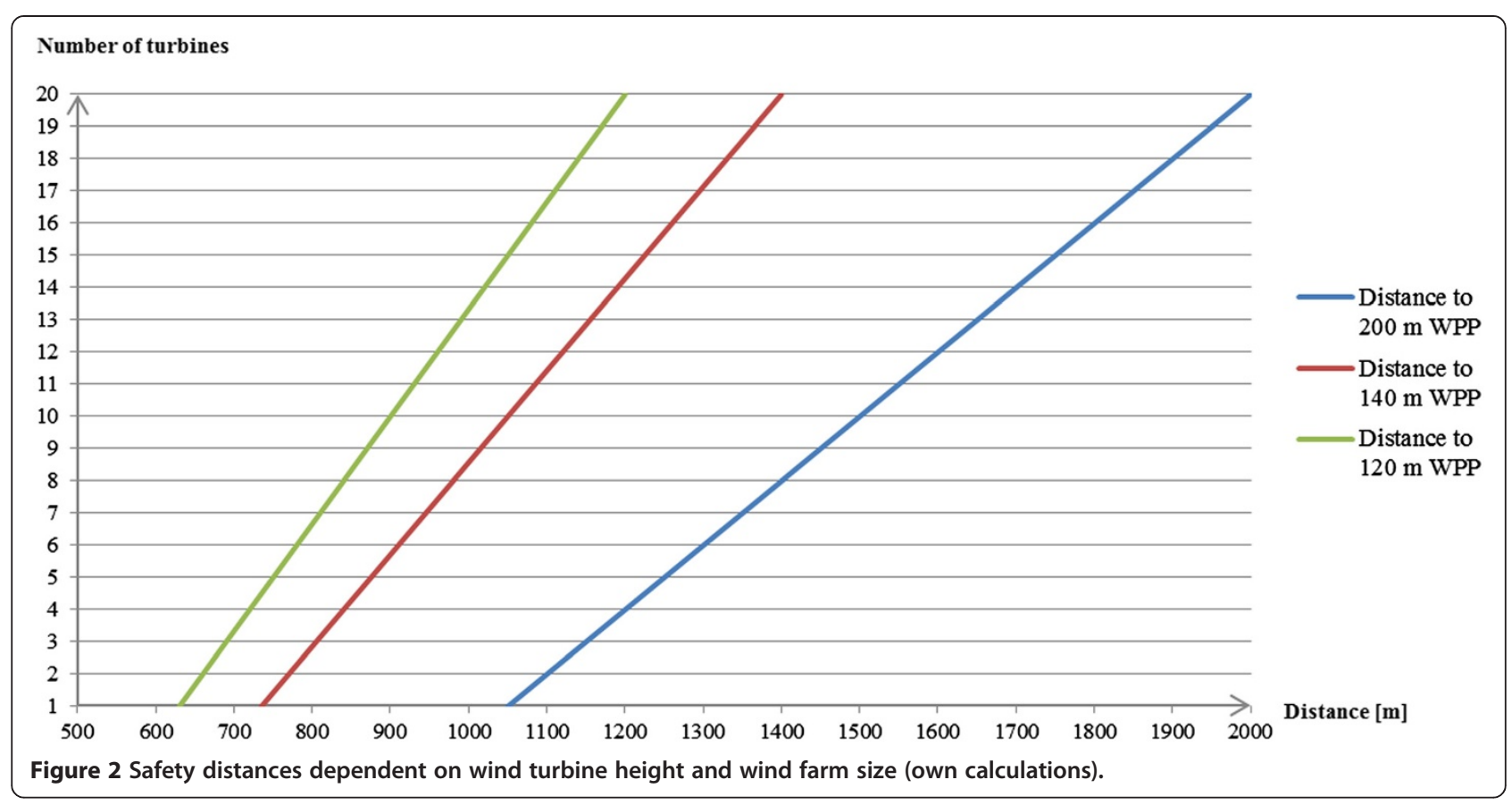

number of wind power plants))' which allows for sufficient safety distances toward large wind parks and repowering scenarios. If a factor ' 0.02 ' is taken into account, the formula would describe the static safety distance in the existing regulations for only one spin wheel. Therefore, some of the existing regulations would not likely guarantee a sufficient emission protection in the case of large wind parks. With a factor '0.05' (Figure 2), safety distances would be high enough. However, for a more precise quantification of this formula, further studies including measurements would be desirable to calibrate the formula in detail. Also, the sound levels of selected turbine types would have to be regarded in individual cases.

This conceptual approach should serve as an input for the discussion of dynamic dimensioning of safety distances to housing areas and for further thoughts on their design. Based on a dynamic calculation considering the variable parameters plant height and turbine number, it would be possible to assess emission effects of large wind park projects more precisely and to improve the protection of affected residential areas. In that case, the planning decision would take the safety requirements better into account.

A dynamic approach would imply an increasing planning effort for the spatial planning discipline, because a case-by-case assessment will become necessary, which also will features a higher complexity due to variable parameters. The planning process for priority zones for wind farms would happen as an iterative process between safety distance intervals and assumptions about appropriate power plant heights and wind turbine numbers, e.g. a smaller height would allow for more turbines in a wind field or vice versa. Therefore, the zoning should set limits on these two parameters, and planners would be methodologically empowered to take both aspects into account.

\section{Conclusions}

Considering the political agenda on wind power expansion and the environmental effects of its large-scale usage, the spatial regulation of wind power expansion plays a key role for its realization and public acceptance. Spatial planning has got tools to regulate the expansion and to mitigate potential conflicts with stakeholders from nature conservation and tourism as well as the affected public. The most essential spatial planning approach is the determination of priority and exclusion areas for the use of wind power based on functional criteria.

For the protection of local residents and affected housing areas, safety distance regulations are applied. Currently, almost all of these distance regulations are defined as static distance values. Considering the technical state and the further development of wind power systems, the dimensioning of static distances and its non-adjustable design arises the question if this approach still is applicable: not only the height of the spin wheels rose considerably in the last years due to the fast technical development in wind power plant construction, but also the number of spin wheels in a wind farm is considerably influencing noise emissions caused by wind farm development. 
To take these developments better into account, safety distance regulations should be dynamically bound to power plant height and wind farm size. With our dynamic approach that was made operational with the proposed formula, cumulative environmental effects by large wind farms as well as variants concerning the height of wind power plants in relation to the number of spin wheels could be considered adequately in spatial planning. The formula can be justified by existing knowledge about emission patterns of wind power plants. The dynamic safety distance approach may lead to better acceptance by local residents. Yet, this approach does not cover issues like bat and bird protection or visual impact assessment, which still have to be carried out on a case-by-case examination. Concerning nature conservation issues, it should be clarified in further research, if the proposed dynamic safety distance approach would be suitable to determine protection distances between wind farm developments and nature protection areas.

\section{Competing interests}

The authors declare that they have no competing interests.

\section{Authors' contributions}

The article was jointly prepared by GF and GS. Both authors read and approved the final manuscript.

\section{Received: 7 August 2014 Accepted: 2 October 2014}

\section{. .}

\section{References}

1. European Parliament and European Council (2009) Decision Nr. 406/2009/ EC, Decision of the European parliament and of the council of 23rd of April 2009 on the effort of member states to reduce their greenhouse gas emissions to meet the Community's greenhouse gas emission reduction commitments up to 2020. Official Journal of the European Union L 140 http://eur-lex.europa.eu/LexUriServ/LexUriServ.do?uri=OJ: L:2009:140:0136:0148:EN:PDF, last accessed on 29/7/2014

2. European Commission (2011) Communication from the Commission to European Parliament, the Council, the Europe Economic and Social Committee and the Committee of the Regions. Energy Roadmap $2050 \mathrm{http}: / /$ ec.europa. eu/energy/energy2020/roadmap/doc/com_2011_8852_en.pdf, last accessed on 29/7/2014

3. European Biodiesel Board (2014) Nationaler Aktionsplan für erneuerbare Energie gemäß der Richtlinie 2009/28/EG zur Förderung der Nutzung von Energie aus erneuerbaren Quellen. Bundesrepublik Deutschland http://www.ebb-eu.org/legis/ActionPlanDirective2009_28/national_ renewable_energy_action_plan_germany_de.pdf, last accessed on 26/10/ 2014

4. Fraunhofer Institut für Windenergie und Energiesystemtechnik (2014) Windenergie Report Deutschland 2013. Kassel http://windmonitor.iwes fraunhofer.de/bilder/upload/Windenergie_Report_Deutschland_2013.pdf, last accessed on 29/7/2014

5. Ökostromgesetz (2012) BGBI. I Nr. 75/2011 idF 11/2012. https:/www.ris.bka.gv. at/GeltendeFassung.wxe?Abfrage=Bundesnormen\&Gesetzesnummer=20007386, last accessed on 26/10/2014

6. IG Windkraft (2014) Präsentationsmaterial der IG Windkraft. St. Pölten http:// www.igwindkraft.at/mmedia/download/2014.01.08/1389206076605739.pdf, last accessed on 29/7/2014

7. E-Control (2013) Statistikbroschüre 2013. E-Control Austria. Wien http:// www.e-control.at/portal/page/portal/medienbibliothek/publikationen/ dokumente/pdfs/Statistikb13_D_Einzelseiten.pdf, last accessed on 29/7/ 2014

8. Sathaye J, Lucon O, Rahman A, Christensen J, Denton F, Fujino J, Heath G, Kadner S, Mirza M, Rudnik H, Schlaepfer A, Shmakin A (2011) Renewable
Energy in the Context of Sustainable Energy. In: IPCC Special Report on Renewable Energy Sources and Climate Change Mitigation. Cambridge University Press, Cambridge and New York, http://srren.ipcc-wg3.de/report/ IPCC_SRREN_Ch09.pdf, last accessed on 29/7/2014

9. Stoeglehner G, Narodoslawsky M (2012) Biofuels — the optimal second best solution? Green Energy \& Technology 2012:100-110

10. Klinski S, Buchholz H, Rehfeldt K, Schulte M, Nehls G (2007) Entwicklung einer Umweltstrategie für die Windenergienutzung an Land und auf See. Endbericht. Umweltbundesamt, Berlin, http:/tu-dresden.de/die_tu_dresden/ fakultaeten/juristische_fakultaet/jitur2/forschung/Umweltstrategie\%20Wind \%20Endbericht\%20endg..pdf, last accessed on 26/10/2014

11. Stanzer G, Spanring C (2004) Windparks: GIS-gestützte Planungsmethoden zur räumlichen Steuerung. CORPKompetenzzentrum für Stadtplanung und Regionalentwicklung. In: CORP 2004. Tagungsband: Computergestützte Raumplanung. Beiträge zum 9. Symposion zur Rolle der Informationstechnologie in der Stadt- und Raumplanung sowie zu den Wechselwirkungen zwischen realem und virtuellem Raum., pp 677-681, http://www.corp.at/archive/ CORP2004_STANZER_SPANRING.pdf, last accessed on 29/7/2014

12. Enercon (2011) Prognostizierter Schallleistungspegel der ENERCON E-101, Betriebsmodus I (Datenblatt). Enercon GmbH. Dreekamp http://www.landkreis-heilbronn.de/sixcms/media.php/236/Hardthausen_4_prognostizierter_Schallleistungspegel_E-101.pdf, last accessed on 29/7/2014

13. Vestas (n.y.) V112-3.0 MW. One turbine for one world. Vestas Wind Systems A/S. Alsvej http://www.vestas.com/Files\%2FFiler\%2FDE\%2FBrochures\%2FVestas_ V112_web_DE.pdf, last accessed on 29/7/2014

14. Wikipedia (2014) Sound pressure http://en.wikipedia.org/wiki/Sound_ pressure, last accessed on 29/7/2014

15. Landesamt für Natur, Umwelt und Verbraucherschutz Nordrhein-Westfalen (2002) Windenergie und Immissionsschutz. Materialien Nr. 63. Landesumweltamt Nordrhein-Westfalen. Essen http://www.lanuv.nrw.de/veroeffentlichungen/ materialien/mat63/mat63_web.pdf, last accessed on 29/7/2014

16. Piorr D (2013) Vortrag von DI Detlef Piorr zum Thema "Immissionsschutz" im Zuge der Informationsveranstaltung zum Windenergie-Erlass NRW 2011 am 21.11.2011 für die Kommunen im Regierungsbezirk Münster. Landesamt für Natur, Umwelt und Verbraucherschutz NRW https://www. bezreg-muenster.de/startseite/Dez_32_Regionalplan-2012/Windenergie/ 6-Windenergie-Erlass_Immsisionschutz_2.pdf, last accessed on 29/7/2014

17. Länderausschuss für Immissionsschutz (2002) Hinweise zur Ermittlung und Beurteilung der optischen Immissionen von Windenergieanlagen (WEA-Schattenwurf-Hinweise). Anlage $2 \mathrm{http} / / / \mathrm{www}$.bauen-wohnen.sachsen. de/download/Bauen_und_Wohnen/HE_Anlage_Schattenwurf.pdf, last accessed on 29/7/2014

18. Bayerisches Landesamt für Umwelt (2013) Schattenwurf von Windkraftanlagen: Erläuterung zur Simulation. Bayerisches Landesamt für Umwelt http://www.energieatlas.bayern.de/file/pdf/1099/Erl\%C3\% A4uterungen\%20zur\%20Schattensimulation\%20von\%20Windkraftanlagen. pdf, last accessed on 29/7/2014

19. Bundesverband Windenergie e.V (2012) Windenergie in Bürgerhand. Energie aus der Region für die Region. Berlin http://www.wind-energie. de/sites/default/files/download/publication/windenergie-buergerhand/ bwe_broschuere_buergerwindparks_10-2012.pdf, last accessed on 29/7/2014

20. Amt der Kaerntner Landesregierung (2012) Verordnung der Kärntner Landesregierung vom 25. September 2012, ZI. 03-Ro-ALL-373/38-2012, mit der ein Sachgebietsprogramm für Standorträume von Windkraftanlagen erlassen wird (Windkraftstandorträume-Verordnung). https://www.ris.bka.gv at/Dokumente/Lgb//LGBL_KA_20121010_100/LGBL_KA_20121010_100.pdf, last accessed on 29/7/2014

21. Scheidler A (2010) Die planerische Steuerung von Windkraftanlagen auf örtlicher und überörtlicher Ebene. Zeitschrift für Landes- und Kommunalrecht. Heft 2 (2010). Nomos Verlag. Baden-Baden http://www.lkrz.nomos.de/?id= 1406 , last accessed on 29/7/2014

22. Strauch C (2004) Windenergienutzung in Mecklenburg-Vorpommern. Planung von Eignungsräumen für Onshore-Windenergieparks. Coastline Reports 1(2004):261-266

23. Köck W, Bovet J (2008) Windenergieanlagen und Freiraumschutz. Rechtliche Anforderungen an die räumliche Steuerung von Windenergieanlagen. Natur und Recht 30:529-534

24. Grellet $L$ (2010) Windenergienutzung in Europa. Rechtliche Fragestellungen rund um die Errichtung und den Betrieb von Windenergieanlagen. Springer Verlag, Wien 
25. Bund-Länder-Initiative Windenergie (2013) Überblick zu den landesplanerischen Abstandsempfehlungen für die Regionalplanung zur Ausweisung von Windenergiegebieten. Stand Mai $2013 \mathrm{http} / / \mathrm{mmw}$. erneuerbare-energien.de/EE/Redaktion/DE/Downloads/Berichte/2013_05_01 ueberblick_zu_den_landesplanerischen_abstandsempfehlungen_fuer_die_ regionalplanung_zur_ausweisung_von_windenergiegebieten.pdf?_blob= publicationfile\&v=4, last accessed on 26/10/2014

26. Deutscher Naturschutzring (2012) Grundlagenarbeit für eine Informationskampagne "Umwelt- und naturschutzverträgliche Windenergienutzung in Deutschland (onshore)". Analyseteil. Ingenieurbüro für Umweltplanung SCHMAL +RATZBOR. Lehrte-Aligse http://www.wind-ist-kraft.de/wp-content/uploads/DNR-WindkraftGrundlagenanalyse-2012.pdf, last accessed on 29/7/2014

27. Cattin R (2008) Alpine Test Site Guetsch. Handbuch und Fachtagung Schlussbericht. Meteotest. Bern http://www.meteotest.ch/fileadmin/ user_upload/Windenergie/pdfs/090403_handbuch_v2.pdf, last accessed on 20/9/2014

28. Bayerisches Landesamt für Umwelt (2011) Schalltechnische Planungshinweise für Windparks. Bayerisches Landesamt für Umwelt. Augsburg http://www.region-westmittelfranken.de/upmedia/Anlage\%202. pdf, last accessed on 29/7/2014

29. Piorr D (2014) Ausweisung von Konzentrationszonen für Windenergieanlagen und Immissionsschutz (draft 22.5.2014, not yet published and provided by the author)

30. Studiotechnik Aufnahmetechnik Tontechnik Forum Sengpielaudio Loudness Comparison Chart. http://www.sengpielaudio.com/ TableOfSoundPressureLevels.htm, last accessed on 20/9/2014

31. Bayerisches Landesamt für Umwelt (2012) Umweltwissen: Windenergie in Bayern. Bayerisches Landesamt für Umwelt, Augsburg, http://www.lfu. bayern.de/umweltwissen/doc/uw_118_windenergie_in_bayern.pdf, last accessed on 29/7/2014

32. 32. Agora Energiewende (2013) Entwicklung der Windenergie in Deutschland. Eine Beschreibung von aktuellen und zukünftigen Trends und Charakteristika der Einspeisung von Windenergieanlagen. Kurzstudie. Agora Energiewende. Berlin http://www.agora-energiewende.de/fileadmin/ downloads/publikationen/ Agora_Kurzstudie_Entwicklung_der_Windenergie_in_Deutschland_web.pdf, last accessed on 29/7/2014

doi:10.1186/s13705-014-0022-8

Cite this article as: Felber and Stoeglehner: Onshore wind energy use in spatial planning - a proposal for resolving conflicts with a dynamic safety distance approach. Energy, Sustainability and Society 2014 4:22.

\section{Submit your manuscript to a SpringerOpen ${ }^{\circ}$ journal and benefit from:}

- Convenient online submission

- Rigorous peer review

- Immediate publication on acceptance

- Open access: articles freely available online

- High visibility within the field

- Retaining the copyright to your article

Submit your next manuscript at $\gg$ springeropen.com 